\title{
Polymerase Chain Reaction-Denaturing Gradient Gel Electrophoresis (PCR-DGGE) Profile of Bacterial Community from Agricultural Soils in Bauchi, North-East Nigeria
}

\author{
Ahmed Faruk Umar*, Fatimah Tahir, Ediga Bede Agbo \\ Department of Microbiology, Abubakar Tafawa Balewa University, Bauchi, Nigeria \\ Email: ^likitacool@yahoo.co.uk
}

How to cite this paper: Umar, A.F., Tahir, F. and Agbo, E.B. (2017) Polymerase Chain Reaction-Denaturing Gradient Gel Electrophoresis (PCR-DGGE) Profile of Bacterial Community from Agricultural Soils in Bauchi, North-East Nigeria. Advances in Microbiology, 7, 480-486.

https://doi.org/10.4236/aim.2017.76037

Received: April 23, 2017

Accepted: June 17, 2017

Published: June 20, 2017

Copyright $\odot 2017$ by authors and Scientific Research Publishing Inc. This work is licensed under the Creative Commons Attribution International License (CC BY 4.0).

http://creativecommons.org/licenses/by/4.0/

\begin{abstract}
The population dynamics of bacterial community was investigated in three Agricultural soils, designated as Loamy sand (A), Peaty coarse (B) and Loamy coarse sand (C) in North-East, Nigeria. The soil chemical properties were characterized to fully understand their nature. Metagenomic approach was used to extract soil DNA using the fast DNA Spin Kit extraction technique. The PCR-electrophoresed DNA bands were excised and subjected to a full scale Denaturing Gradient Gel Electrophoresis (DGGE) analysis. DGGE fingerprinting for the PCR-16S rDNA product revealed a diverse profile of complex population of bacterial community in the study area. The study shows that more bacterial community can be fully investigated using molecular techniques rather than traditional culture method. The implication of the results obtained is discussed.
\end{abstract}

\section{Keywords}

Metagenomic, Fingerprinting, Bacterial Community, PCR-DGGE, Culture Method

\section{Introduction}

Microorganisms are key players in important ecological processes such as soil structure formation, decomposition of organic matter and xenobiotic, recycling of essential elements (e.g. carbon, nitrogen, phosphorous and sulphur) [1]. A fully developed soil is an intricate mixture of inorganic and organic components, a complex product of parent materials, topography, climate, time and biological activities [2]. In an average fertile loamy soil (a good agricultural soil), mineral 
matter from weathered rock usually accounts for some $50 \%$ by volume, and organic matter from plant, animals and microorganisms for 10\% - 15\% [3]. In a balanced soil, plants grow in an active and vibrant environment. The mineral content of the soil and its physical structure are important for their well-being, but it is the activity of microorganisms that powers its cycles and provides increased fertility. Without the activities of soil organisms, organic materials would accumulate and litter the soil surface, and in effect no food for plants [4].

The need to understand the microbial community that channel soil affair is quite imperative. These will pave way in knowing their activities and mechanistic role to the sustenance of ecosystem (e.g. energy flow, biogeochemical cycling, and ecological resilience). The target organisms, example bacteria are often incompletely assessed during traditional culture techniques, such as pour plate or even soil dilution methods. Advances in genomic and sequencing technologies have paved way for proper understanding of the complex nature of soil environment. This study intends to use the science of metagenomics to bring fore the nature of the bacterial community in three agricultural soils in Bauchi State North-Eastern Nigeria. It will involve the use of Polymerase Chain ReactionDenaturing Gradient Gel Electrophoresis (PCR-DGGE) fingerprinting as a whole community analysis method. Other molecular approaches such as metaproteomics, metatranscriptome, and proteogenomics are vital for discovering and characterizing the vast microbial diversity and understanding their interactions with abiotic and biotic environmental factors [1] [5].

The PCR-DGGE has the advantage of not requiring previous knowledge on microbial population. It has rapid and efficient separation technique of same length DNA sequence (amplified by PCR), which may vary a little as a single pair modification [6]. PCR-DGGE is also flexible that allows a unique combination of different approaches for a more accurate identification of functional genes present in particular bacterial population by using hybridization or species-specific probes.

\section{Materials and Methods}

\subsection{Sampling and Study Area}

Soil samples were collected from three agricultural lands in Bauchi state, Northeast, Nigeria. Agricultural activities are actively carried out on the loamy sand (A), and peaty coarse sand (B), while loamy coarse sand (C) was used for organic farming only.

Surface soils were sampled by removing the top $10 \mathrm{~cm}$ of soil surface with hand trowel. Approximately $100 \mathrm{~g}$ each were collected in replicates from each agricultural land [7]. Soil samples were made in composite from the designated areas and transported in clean polythene container on ice-pack cooling system [8].

\subsection{Characterization of Soil Samples}

Techniques used for the investigation of soil samples include, Soil pH determi- 
nation using 1:1 (soil to water method, soil temperature determination using mercury-in-glass thermometer. Other analysis carried out involves determination of organic carbon, total nitrogen, soil particle size and available phosphorous, using Wakley and Black method [9], Macro-kjedhal method, hydrometer method and Bray No.1 method, respectively. The exchangeable cations were determined using the Silver-Thiourea extraction method.

\subsection{Isolation of Soil DNA (Using Fast DNA Spin Kit)}

DNA was isolated from soil samples using the fast DNA spin kit for soil fast prep instrument. Five hundred milligram $(500 \mathrm{mg}$ ) of soil sample was placed into a lysin matrix E tube. Also, $978 \mu \mathrm{l}$ of Sodium phosphate buffer was added to the tube. This was followed by the addition of $122 \mu \mathrm{MT}$ buffer. The set-up was homogenized in the fast prep instrument at a speed of 6.0 for 4.0 seconds. The preparation was further centrifuged at 14,000 rpm for several minutes. The supernatant was transferred to a $2 \mathrm{ml}$ eppendorf tube and $250 \mu \mathrm{l}$ protein precipitation solution (PPS) was added, inverted by hand 10 times. The set-up was centrifuged at 14,000 rpm for 5 minutes and supernatant transferred to another $2 \mathrm{ml}$ eppendorf tube. $1 \mathrm{ml}$ of binding matrix suspension was added to the tube. The preparation was placed on a rotator for 2 minutes and allowed to stand for further 3 minutes. $500 \mu \mathrm{l}$ of supernatant was carefully removed avoiding the binding matrix. An approximate volume of $600 \mu \mathrm{l}$ of the matrix was transferred to a $\operatorname{spin}^{\mathrm{TM}}$ filter and centrifuged at 14,000 rpm for 1 minute. The catch-tube was replaced twice and $500 \mu \mathrm{l}$ prepared SEWS-M was used to resuspend the pellets. The set-up was centrifuged at 14,000 rpm for 3 minutes and catch tube was replaced, by a clean one. The SPIN ${ }^{\mathrm{TM}}$ filter was air dried at room temperature. 50 $\mu \mathrm{l}$ of DNase/pyrogen-free water placed above the SPIN ${ }^{\mathrm{TM}}$ filter to resuspend binding matrix pellet. The set-up was centrifuged at $14,000 \mathrm{rpm}$ for 1 minute to elute DNA into the clean catch tube. SPIN ${ }^{\mathrm{TM}}$ filter was discarded and DNA was kept at $-20^{\circ} \mathrm{C}$ in tube for further application.

\subsubsection{Polymerase Chain Reaction (PCR) Analysis}

PCR amplification of 16S r RNA genes was carried out using the forward primer/63F and reverse primer/1387R. The amplification reaction was performed with ESCO-MAXI swift thermocycler PCR machine. PCR reaction on DNA samples were carried out using a standard set-up of $18.1 \mu \mathrm{l}$ of distilled water, 2.5 $\mu \mathrm{l}$ of buffer, $1 \mu \mathrm{l}$ of forward and reverse primers, $0.4 \mu \mathrm{l}$ Tag polymerase and $1 \mu \mathrm{l}$ of DNA template per reaction. Each reaction setting was mixed in a $0.2 \mathrm{ml}$ PCR tube. The preparation was loaded on the PCR machine and lid fastened. The program used was 1 cycle of $95^{\circ} \mathrm{C}$ for 5 minutes; 32 cycles of $95^{\circ} \mathrm{C}$ for 45 seconds; $55^{\circ} \mathrm{C}$ for 45 seconds; $72^{\circ} \mathrm{C}$ for 2 minutes, followed by a final extension of $72^{\circ} \mathrm{C}$ for 10 minutes. Amplification product were visualized after separation by electrophoresis in a $1 \%$ agarose gel and stained with $0.5 \%$ ethidium bromide. Results were visualized using UV-transilluminator versadoc imager.

\subsubsection{Denaturing Gradient Gel Electrophoresis (DGGE) Probe}

Confirmed 16S r RNA PCR products from soil DNA were subjected to GC 
clamp-PCR analysis with group specific oligonucleotide probes. The nucleotide sequences of the primers are as follows:

p2-5'ATTACCGCGGCTGCTGG-3' and p35'CGCCCGCGCGCGCGGCGGGGCGGGGCGGGGGCACGGGGGCCTAC GGGAGGCAGCAG-3’.

A combination of $\mathrm{p} 2$ and $\mathrm{p} 3$ primers was used to amplify the $16 \mathrm{~S}$ rDNA regions. PCR amplification was performed with a DNA machine DYAD thermocycler using $1 \mu \mathrm{l}$ of PCR lysate, $1 \mu \mathrm{l}$ of each p2 and p3, $1 \mu \mathrm{l}$ of DNTPs, $2.5 \mu \mathrm{l}$ buffer, $1.8 \mu \mathrm{l}$ of sterile water and $0.4 \mu \mathrm{l}$ of taq polymerase. Each reaction was placed in $0.2 \mathrm{ml} \mathrm{PCR}$ tube. The program used was $95^{\circ} \mathrm{C}$ for 5 minutes, $95^{\circ} \mathrm{C}$ for 1 minute, and $65^{\circ} \mathrm{C}$ for 1 minute for 20 cycles, decreased by $0.5^{\circ} \mathrm{C}$ in every cycle, and incubated at $72^{\circ} \mathrm{C}$ for 3 minutes. This was followed by incubation for $95^{\circ} \mathrm{C}$ for 1 minute, $55^{\circ} \mathrm{C}$ for 1 minute and $72^{\circ} \mathrm{C}$ for 1 minute for 5 cycles. Final incubation was carried out at $72^{\circ} \mathrm{C}$ for 3 minutes. Confirmed PCR-GC clamp products were loaded onto DGGE Bio-Rad gel electrophoresis system, with an already loaded casket of acryl amide based gel. The DCODE buffer chamber was filled to the required level with Tris acetate electrophoresis buffer. The buffer in the DCODE apparatus was pre-heated to $60^{\circ} \mathrm{C}$. When the temperature was about $50^{\circ} \mathrm{C}$, heating was interrupted and the gel plates were attached to the core assembly. The gel comb was removed and wells rinsed with water inside the DCODE system. About $15 \mu \mathrm{l}$ of PCR product with $3 \mu \mathrm{l} 6 \times$ loading dye were carefully loaded. The lid was placed back on the electrophoresis tank and system switched. The run was performed at 17 hours at 90 volts. Gel was disassembled from casket by carefully removing one glass plate. The gel was placed in a tray with cyber-gold staining solution, incubated for 30 minutes and analyzed using UV-transilluminator VERSADOC imager.

\section{Results and Discussion}

The bacterial community survey of soil samples investigated is loamy sand (A), peaty coarse sand (B) and loamy coarse sand (C). The characterization of the properties of the soils studied is summarized in Table 1. Data were shown for parameters, e.g. nutritional status (organic Carbon, total Nitrogen, and available Phosphorus) and particle size. Of the 3 soils evaluated, organic matter content was observed $(0.09 \%$ to $9.08 \%)$. Most of the soils were peaty coarse sand to loamy soil (mean silt average of approximately $8 \%$ ). Soil $\mathrm{pH}$ ranged from moderately acidic to slightly above neutral (5.2 to 7.1 ) (Table 1 ). The soil C had higher percentage of both aerobic heterotrophic bacterial populations (data not shown). Environmental conditions can also be improved to get optimal values of microbial degradation e.g. moisture content [10]. The initial soil moisture, in percentage, for the three soils studied ranged between $16 \%$ and $24 \%$ (Table 1), but this can be subjective, as changes can occur through seasonal influence and organic amendment supplementation.

The direct DNA isolation from soils studied showed high percentage of bacterial community in the soil samples studied. The DNA concentrations were 
Table 1. Physical and chemical properties of soil in the three sampling sites.

\begin{tabular}{|c|c|c|c|}
\hline \multirow[b]{2}{*}{ Soil types } & \multicolumn{3}{|c|}{ Sampling sites } \\
\hline & $\begin{array}{l}\text { Loamy sand } \\
\text { (A) }\end{array}$ & $\begin{array}{l}\text { Peaty coarse } \\
\text { (B) }\end{array}$ & $\begin{array}{c}\text { Loamy } \\
\text { Coarse (C) }\end{array}$ \\
\hline Temperature $\left({ }^{\circ} \mathrm{C}\right)$ & 28 & 27 & 30 \\
\hline $\mathrm{pH}$ & 6.2 & 7.1 & 5.2 \\
\hline Organic carbon (\%) & 0.90 & 1.44 & 1.25 \\
\hline Total nitrogen $(\%)$ & 0.09 & 0.24 & 0.10 \\
\hline Available phosphorus (mg/kg) & 8.09 & 8.01 & 9.08 \\
\hline Initial soil moisture (\%) & 18 & 24 & 16 \\
\hline \multicolumn{4}{|c|}{ Exchangeable cations ( $\mathrm{Cmol} / \mathrm{mg})$} \\
\hline K & 0.01 & 0.03 & 0.02 \\
\hline $\mathrm{Ca}$ & 0.80 & 0.78 & 0.95 \\
\hline $\mathrm{Mg}$ & 0.02 & 0.04 & 0.06 \\
\hline $\mathrm{Na}$ & 0.01 & 0.10 & 0.01 \\
\hline \multicolumn{4}{|c|}{ Particle size (\%) } \\
\hline Sand & 85 & 87 & 61.5 \\
\hline Silt & 7 & 7 & 10.5 \\
\hline Clay & 8 & 6 & 28.0 \\
\hline
\end{tabular}

Values were taken from composite soil sample and average of three replications.

over and above the average $3000 \mathrm{~kb}$ on the molecular ladder used during electrophoresis. The three soil samples provided high quality DNA probe, as confirmed and quantified by gel electrophoresis (Figure 1).

Likewise, to further determine complex nature of microbial community, the Denaturing Gradient Gel Electrophoresis (DGGE) fingerprinting of the three soils was carried out. The PCR-DGGE analysis provided a well-defined comparison for the microbial composition of the various soil samples (Figure 2). The DGGE profile showed a more complex mixture of microbial group in $\mathrm{C}$, as observed with the presence of many distinguishable bands in the separation pattern, most likely derived from as many different bacterial species constituting the population. Although not clearly visible in Figure 2, the bands formation for the three soil samples analyzed showed high differentiation in microbial species type. This can provide a strong argument that the aerobic heterotrophic bacteria count observed by cultivation based is obscure. The DGGE technique for studying microbial diversity is superior to cultivation method and subsequent sequencing of PCR-amplified r DNA or ribosomal copy of DNA fragments. First, it provides an immediate display of the constituents of a population in both a qualitative and semi-quantitative way, and second, it is less time consuming and non-laborious [11]. In the natural microbial population which was analyzed provided high probability of mixed microbial population species. Also, bands at identical positions in the DGGE gels are not necessarily derived from the same species. This problem can be addressed by exploiting a particular advantage of DGGE i.e. using more narrow gradients to provide high resolution DGGE profiles 


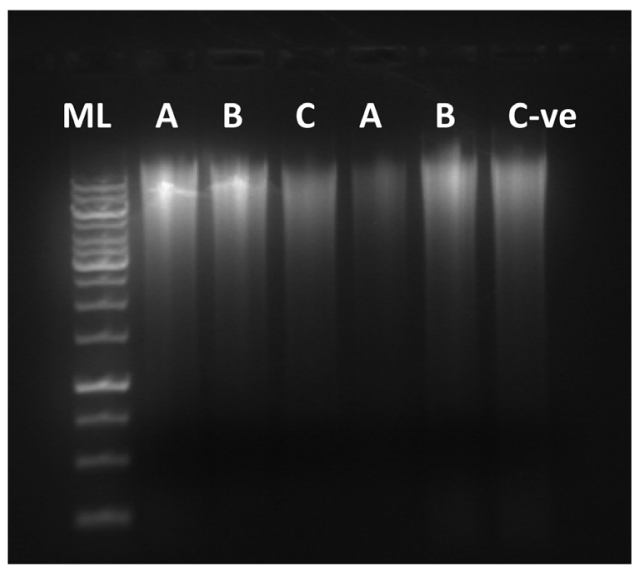

Figure 1 . Scanned image of $0.5 \%$ ethidium bromide-stained agarose gel of the total genomic DNA extract from the soil samples used in the study.

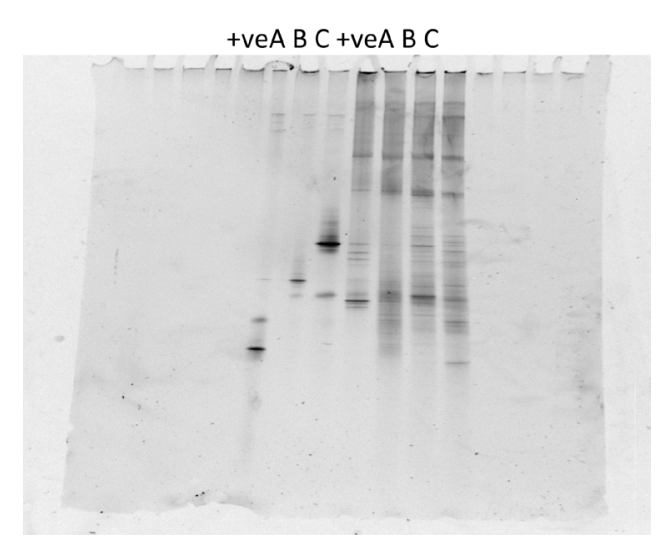

Figure 2. Scanned image of Cybr-gold stained PCR DGGE gel profile of the bacterial communities from the different soil samples used during the study.

of particular part of the original profile. In the analysis conducted, two approaches were jointly carried out on PCR products used in GC-clamp set-up. Brighter bands, with fully differentiated separation were observed in purified 16s $r$ RNA products, though this is usually done for convenience sake.

Specific hybridization and characterization of the band were not carried out to ascertain microbial types within mixed population studied.

\section{References}

[1] Rastogi, G. and Sani, R.K. (2005) Molecular Techniques to Assess Microbial Community Structure, Function and Dynamics in Environment. In: Ahmed, et al., Eds., Microbes and Microbial Technology: Agricultural and Environmental Applications, Springer Science.

[2] Atlas, R.M. and Bartha, R. (1981) Stimulated Biodegradation of Oil Slicks Using Oleophillic Fertilizer. Environmental Science \& Technology, 7, 538-541.

https://doi.org/10.1021/es60078a005 
[3] Grant, W.D. and Long, P.E. (1992) Environmental Microbiology. 2nd Edition, Blackwell Publishers, UK, 122-124.

[4] Atlas, R.M. (1981) Microbial Degradation of Petroleum Hydrocarbon: An Environmental Perspective. Microbial Review, 45, 202-219.

[5] Dzantor, E.K., Felsot, A.S., Bicki, T.J. and Hinesly, H. (1992) Phytotoxicity of Atrazine and Alachlorin Soil Amended with Sludge, Manure and Activated Carbon. Journal of Environmental Science and Health Part-B Pesticide Food Contaminants and Agricultural Waste, 26, 513-527.

[6] McAullife, L., Ellis, R.J., Lawes, J.R., Ayling, R.D. and Nicholas, R.A. (2005) $16 \mathrm{~S} r$ DNA-PCR and Denaturing Gradient Gel Electrophoresis: A Single Generic Test for Detecting and Differentiating Mycoplasma Species. Journal of Medical Microbiology, 54, 731-739.

[7] Fletcher, R.D. (2002) Bioremediation of Aviation Oil Spill: An Environmental Alternative. Journal Industrial Microbial, 7, 28-111.

[8] Kruger, E.L., Anhalt, J.C., Sorensen, D., Nelson, B., Chouhy, A.L., Anderson, T.A. and Coats, J.R. (1997) Atrazine Degradation in Pesticide-Contaminated Soils. Phytoremediation, American Chemical Society of Symposium Series 664, Washington DC, 54-64.

[9] Wakley, A. and Black, I.A. (1965) An Examination of the Method for Determining Soil Organic Matter and Proposed Modification of the Acid Titration Method. Journal of Soil Science, 37, 29-38. https://doi.org/10.1097/00010694-193401000-00003

[10] Sarkar, S.F., Guttman, D.S. and Silby, M.W. (2005) Evolution of the Core Genome of Pseudomonas syringae, a Highly Clonal, Endemic Plant Pathogen. Applied and Environmental Microbiology, 70, 1999-2012. https://doi.org/10.1128/AEM.70.4.1999-2012.2004

[11] Moorman, T.B., Cowan, J.K., Arthur, E.L. and Coats, J.R. (2001) Organic Amendments to Enhance Herbicide Biodegradation in Contaminated Soils. Biology and Fertility of Soil, 33, 541-545. https://doi.org/10.1007/s003740100367

Submit or recommend next manuscript to SCIRP and we will provide best service for you:

Accepting pre-submission inquiries through Email, Facebook, LinkedIn, Twitter, etc. A wide selection of journals (inclusive of 9 subjects, more than 200 journals)

Providing 24-hour high-quality service

User-friendly online submission system

Fair and swift peer-review system

Efficient typesetting and proofreading procedure

Display of the result of downloads and visits, as well as the number of cited articles

Maximum dissemination of your research work

Submit your manuscript at: http://papersubmission.scirp.org/

Or contact aim@scirp.org 